K A R L E. CASE

Wellesley College

\title{
Real Estate and the Macroeconomy
}

IN JULY 1987 MASSACHUSETTS governor Michael Dukakis began his run for the presidency in the midst of what was being called the Massachusetts Miracle, with employment growing rapidly and an unemployment rate of 2.4 percent. An economy that had experienced 12.8 percent unemployment and an employment base in secular decline in the mid-1970s had become the fastest-growing region in the country just over a decade later. That summer, however, state revenue began to shrink and real estate sales dropped sharply. By the time of the election in 1988, employment was falling, and it continued to fall until the end of 1991. In all, over 360,000 jobs were lost from a peak of 3.2 million, representing more than 11.5 percent of nonfarm payrolls. Employment declines in the other five New England states were comparable. In a development symptomatic of widespread troubles in the region's banking sector, Bank of New England Corporation, with $\$ 32$ billion in assets, received a CAMEL 5 rating in March 1990 and was closed by the Federal Deposit Insurance Corporation in January $1991 .^{1}$ Its closure imposed net losses on the agency of $\$ 733$ million. $^{2}$

The extensive involvement of real estate in both the 1984-88 boom and the 1988-92 bust in New England has been well documented. ${ }^{3}$ A dramatic rise in housing prices fueled consumer spending, construction

I am grateful to Maryna Marynchenko and Jenny Stack for invaluable research assistance and to Robert Shiller, Ray Fair, John Quigley, and Chris Mayer for insightful discussions on these topics.

1. CAMEL (capital adequacy, asset quality, management, earnings, and liquidity) ratings are early-warning measures used by bank regulators to identify potentially failing banks.

2. Federal Deposit Insurance Corporation (1998).

3. See, for example, Case (1991). 
employment expanded more than 50 percent, and overall employment growth was concentrated in "population serving establishments." ${ }^{4}$ According to call reports (balance sheet reports that banks file each quarter with the Federal Reserve), 72 percent of all bank lending during the boom was collateralized with real estate, and real estate loans accounted for more than 90 percent of Bank of New England's losses. ${ }^{5}$ Mortgage default rates and foreclosure rates were high, and losses were severe. ${ }^{6}$ Higher vacancy rates, lower rents, and higher capitalization rates (defined below) led to sharp declines in commercial real estate values. Similar real estate involvement in the economic cycle had been documented earlier in Texas and was observed later in California, Alaska, and Hawaii.

Today the U.S. economy is in the tenth year of an economic expansion. Both residential and commercial real estate values have been rising steadily across the nation, and the volume of lending collateralized by real estate has grown sharply. This paper explores the involvement of both commercial and residential real estate in the national economic cycle. It considers the role of real estate in the expansion of aggregate demand, the risks to the financial sector from using real estate as collateral, and the distributional consequences of real estate inflation.

\section{The Housing Market}

Table 1 presents some very rough estimates of the size and value of the U.S. housing stock in 1999. The estimates are based on a variety of different but fairly consistent sources. In 1999 there were approximately 103 million housing units occupied year round. About two-thirds of these were owned by their occupants. In addition, 13.4 million units were seasonally occupied or vacant. Of those, 6.1 million were seasonal or for rent.

Table 2 presents national and regional data on housing price rises, based on weighted repeat sales indexes for single-family properties, from the Office of Federal Housing Enterprise Oversight (OFHEO). The table shows that home prices across the nation as a whole were up 6.5 percent

4. Moscovitch (1990). Population-serving establishments are those engaged in retail trade and local services as opposed to export activities.

5. Case (1991).

6. Case and Shiller (1996). 
Table 1. U.S. Housing Stock and Residential Mortgage Debt, End of 1999

Units as indicated

\begin{tabular}{lcccc}
\hline Type of property & $\begin{array}{c}\text { Units } \\
\text { (millions) }\end{array}$ & $\begin{array}{c}\text { Average value } \\
\text { (thousands } \\
\text { of dollars) }\end{array}$ & $\begin{array}{c}\text { Total value } \\
\text { (trillions } \\
\text { of dollars) }\end{array}$ & $\begin{array}{c}\text { Mortgage debt } \\
\text { (trillions } \\
\text { of dollars) }\end{array}$ \\
\hline Owner occupied & 67.5 & 132.0 & 8.9 & 4.6 \\
Rental $^{\mathrm{a}}$ & 35.0 & 65.7 & 2.3 & 0.5 \\
Seasonal or vacant & 13.4 & 27.5 & 0.4 & $\ldots$ \\
Total & 115.9 & $\ldots$ & 11.6 & 5.1 \\
\hline
\end{tabular}

Sources: Author's calculations based on data from Bureau of the Census, American Housing Survey, 1997; Federal Reserve, Survey of Consumer Finances, 1998; Harvard University Joint Center for Housing Studies, State of the Nation's Housing, 1999; Federal Reserve, Flow of Funds Accounts; Office of Federal Housing Enterprise Oversight, House Price Index, first quarter 2000; and Miles and Tolleson (1997).

a. Includes single-family rentals and government-owned and -subsidized rental housing stock.

year over year as of March 2000 and had risen 27.3 percent over five years, for a 4.9 percent compounded annual rate. That would suggest nominal capital gains of approximately $\$ 544$ billion in the previous year and $\$ 1.9$ trillion over five years. Although sizable, these gains are dwarfed by the increase in value of household financial assets over the last five years: the comparable increase in stock market capitalization is over $\$ 8$ trillion. These aggregate figures mask a great deal of regional variation, however, which the rest of this section explores.

Table 2. Changes in Housing Prices by Region as of $\mathbf{2 0 0 0}^{\mathrm{a}}$

Percent

\begin{tabular}{lccc}
\hline Region & One-year & Five-year & Since 1980 \\
\hline New England & 10.2 & 33.4 & 242.8 \\
West North Central & 7.8 & 31.1 & 110.0 \\
Pacific & 7.1 & 28.5 & 166.8 \\
Middle Atlantic & 6.5 & 21.3 & 186.1 \\
East North Central & 6.3 & 30.8 & 139.1 \\
Mountain & 5.9 & 30.3 & 123.4 \\
South Atlantic & 5.7 & 25.1 & 129.4 \\
West South Central & 5.3 & 23.4 & 60.2 \\
East South Central & 3.9 & 26.2 & 117.2 \\
United States $^{\mathrm{b}}$ & 6.5 & 27.3 & 137.8 \\
Memorandum: change in CPI-U $^{\text {Memond }}$ & 3.2 & 12.4 & 105.9 \\
\hline
\end{tabular}

Sources: Office of Federal Housing Enterprise Oversight, House Price Index, first quarter 2000; Bureau of Labor Statistics.

a. Through March.

b. Weighted regional average. 


\section{Home Values}

A panel database of aggregate home values was constructed from repeat sales price indexes applied to the 1990 census median values by state. Case-Shiller (CS) weighted repeat sales indexes constructed by Case Shiller Weiss, Inc. are available for sixteen states. ${ }^{7}$ In addition, OFHEO makes state-level repeat value indexes, produced by Fannie Mae and Freddie Mac, available for all states.

The Case-Shiller indexes are the best available for our purposes, and wherever possible they are used in this paper. Although OFHEO uses a similar methodology to construct its indexes, ${ }^{8}$ these indexes are in part based on real estate appraisals rather than exclusively on arm's-length transactions. CS indexes control, to the extent possible, for changes in property characteristics, and it can be shown that they pick up turns in price direction earlier and more accurately than do the OFHEO indexes. Nonetheless, for purposes of capturing broad movements over long periods, the indexes tend to track each other quite well, and the OFHEO indexes are used in some states for which CS indexes are unavailable in order to achieve broader coverage.

The panel on home prices was constructed as follows for each state:

$$
V_{i}^{t}=r_{i}^{t} N_{i}^{t} v_{i}^{1990: 1} I_{i}^{t},
$$

where

$V_{i}^{t}=$ aggregate home value in state $i$ at time $t$

$r_{i}^{t}=$ the home ownership rate in state $i$ at time $t$

$N_{i}^{t}=$ the number of households in state $i$ at time $t$

$v_{i}^{1990: 1}=$ the mean value of owner-occupied homes in state $i$ in the first quarter of 1990, and

$I_{i}^{t}=$ the weighted repeat sales price index for state $i, 1990: 1=$ 1.0 .

Quarterly data on the number of households and rates of home ownership were obtained by interpolation of annual data from the Current Population Survey of the Census Bureau. The construction allows for 
Figure 1. Aggregate Value of the U.S. Housing Stock, 1982-99a

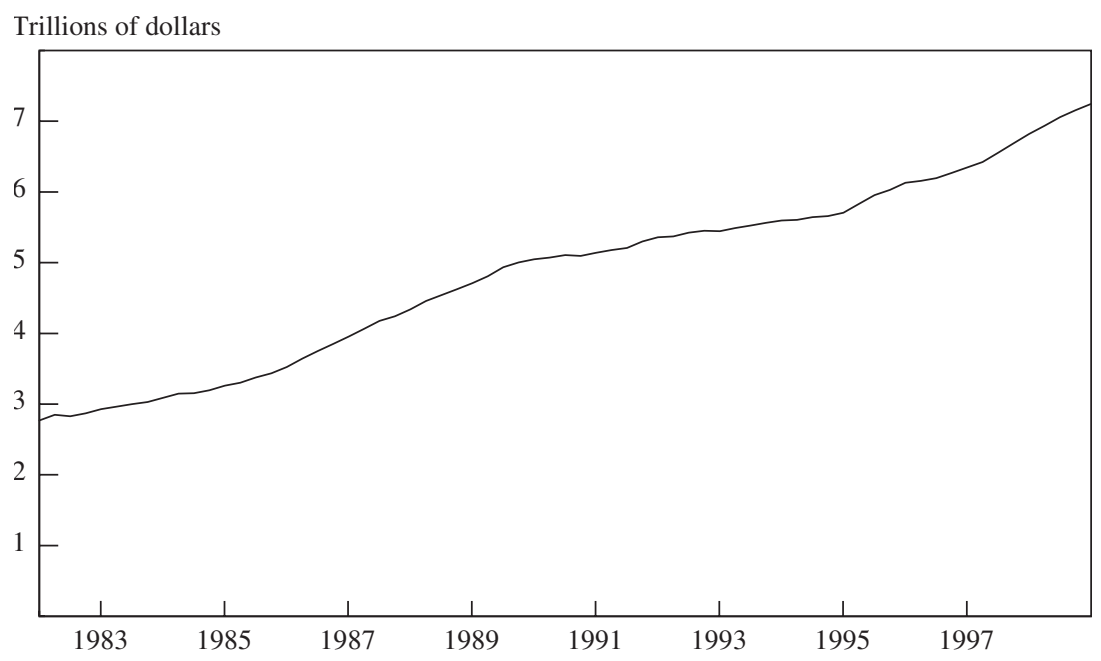

Sources: Author's calculations based on equation (1) in the text and data from Case Shiller Weiss, Inc.; Fannie Mae; Freddie Mac; and Bureau of the Census, Current Population Survey.

a. Using the housing stock in 1990 as a base and controlling for quality improvements and increments to that stock.

increases to the stock from pure appreciation as well as from increases in the number of owner households.

The baseline figures for mean home prices at the state level are based on owners' estimates reported in the 1990 census. A number of studies have attempted to measure the bias in such estimates; the results range from -2 percent to +6 percent. ${ }^{9}$ John Goodman and John Ittner point out that, for purposes of measuring wealth effects, owners' estimates may indeed be the best measure of housing wealth, because consumption behavior is likely to be based on perceived home value.

Figure 1 shows the sum of all the state-level aggregations. The result indicates that the aggregate nominal value of the owner-occupied housing stock in the United States rose from \$2.8 trillion in 1982 to $\$ 7.3$ trillion in 1999. This figure takes as a base the value of the stock in 1990 and attempts to isolate a quality-controlled increase in value. The point is to approximate capital gains and isolate them from increments to the capital stock itself. Hence one should expect this figure, derived from detailed sur-

9. Kain and Quigley (1972) and Follain and Malpezzi (1981) present estimates at the low end of this range, and Goodman and Ittner (1992) at the high end. 
Figure 2. Aggregate Value of Household Financial Assets and Stock Market Capitalization, 1985-99

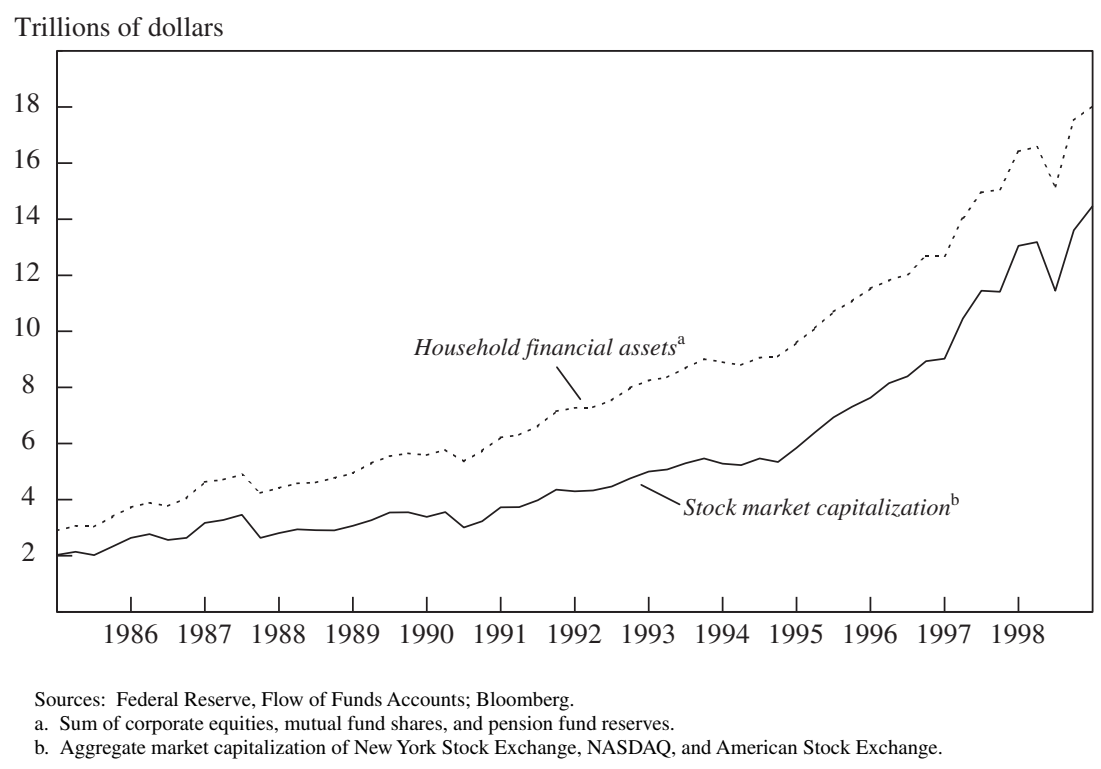

vey data, to be substantially lower than the $\$ 8.9$ trillion total value for the stock in 1999 reported in table 1 . The 20 percent difference should be approximately equal to the net increment to the capital portion of the owner-occupied stock during the period.

\section{The Stock Market}

Data on household financial assets were obtained from the Federal Reserve flow of funds (FOF) accounts and compared with the aggregate market capitalization of the three major stock markets. The FOF accounts report the total value of corporate equities, pension fund reserves, and mutual funds held by the household sector. The FOF series has risen in nominal terms from less than $\$ 3$ trillion in 1982 to $\$ 18$ trillion in 1999 (figure 2). More than half ( $\$ 8.4$ trillion) of the gross increase between 1982 and 1999 occurred during the last four years of the period. Figure 2 also shows a measure of aggregate capitalization of the stock market, demonstrating that nearly all the variation in the FOF data is due to stock market variation. 
Figure 3. Aggregate Value of Housing Stock in Massachusetts, 1982-99a

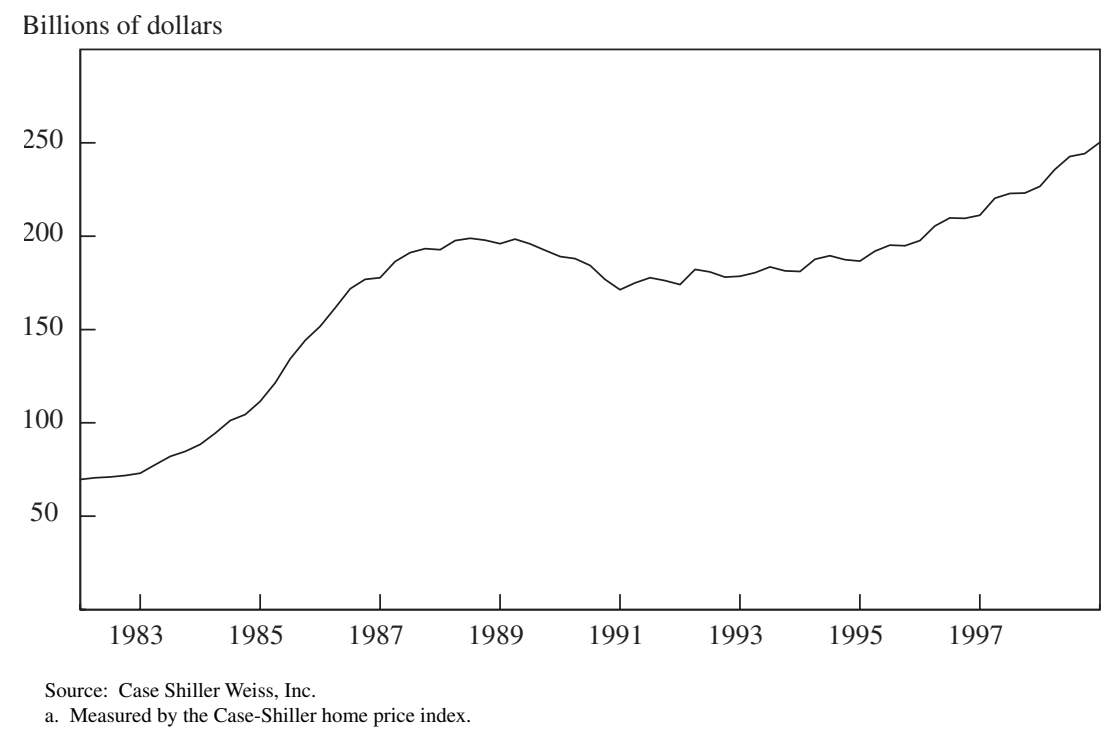

To arrive at a state-by-state distribution of household financial assets, mutual fund holdings by state were obtained from the Investment Company Institute. These data are available for 1986, 1987, 1989, 1991, and 1993. It is then assumed that, for the period 1982:1 to 1986:4, the distribution was the same as it was in 1986, and similarly that the 1993 distribution held for the period 1993-99. It is further assumed that direct household holdings of stocks and pension fund reserves were distributed in the same geographic pattern as mutual fund holdings. This is clearly a heroic assumption, but no alternative data could be found. In addition, the time variation in the state series is virtually all from the national stock market.

\section{How Substantial Are Recent Capital Gains in Equities and Housing?}

The housing price booms in Massachusetts and in California during the 1980s were among the most dramatic in recent times. Figures 3 and 4 show aggregate home value on a quarterly basis for those two states since 1982. During the Massachusetts boom, from 1983:3 to 1988:3, home values increased by $\$ 116.8$ billion, or 21.2 percent of cumulative state personal income (from the national income and product accounts) over the 
Figure 4. Aggregate Value of Housing Stock in California, 1982-99a

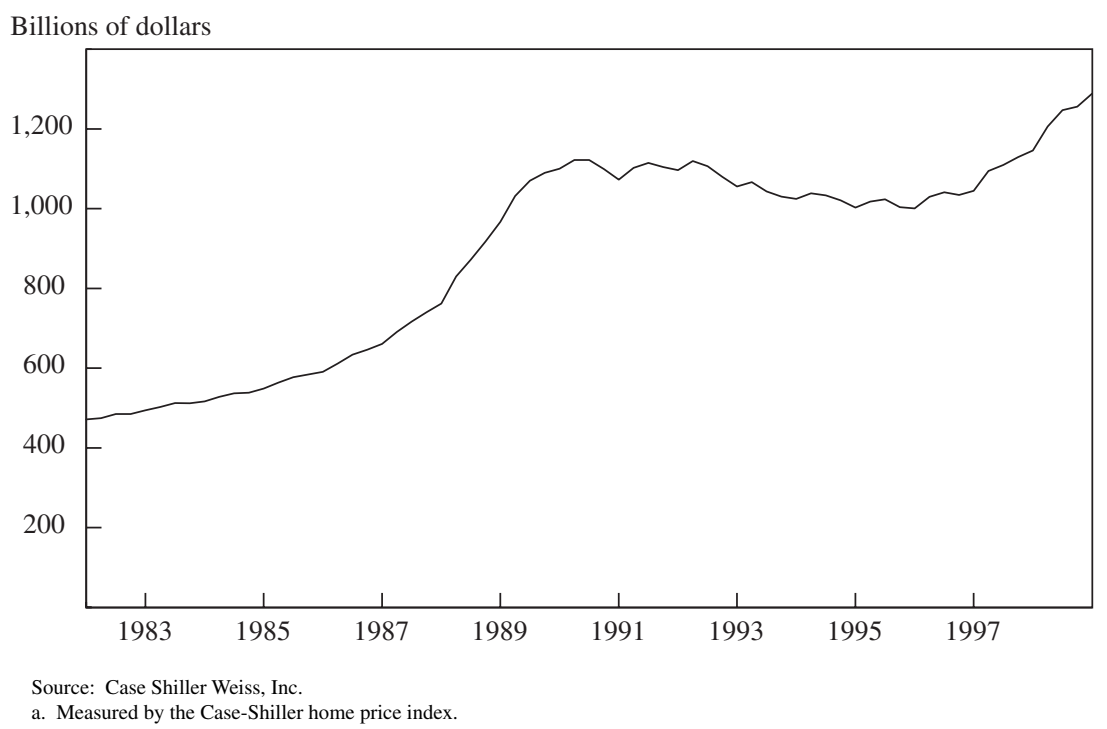

period. The California boom, which lasted from 1985:3 to 1990:3, witnessed an aggregate increase in home value of $\$ 544.8$ billion, or 19.4 percent of cumulative state personal income during the period.

Both booms were followed by busts. Massachusetts gave back $\$ 27.6$ billion in aggregate home value between 1988:3 and 1991:1, or 8 percent of cumulative state personal income. California gave back $\$ 121.5$ billion over the longer period from 1990:3 to 1996:1, although this was only 3.1 percent of state personal income cumulated over that period. The Texas bust between 1986:3 and 1988:3 (not shown) saw a giveback of $\$ 30.6$ billion, or 5.7 percent of cumulative state personal income.

Table 3 gives some indication of the relative magnitude of changes in home and stock market values in a somewhat arbitrarily chosen set of states and time periods. The table shows gross increases in stock market value and in the aggregate value of owner-occupied housing, both as percentages of aggregate state personal income. For example, between 1983:1 and 1986:4, the stock market holdings of households in Arizona increased in value by 14.7 percent of that state's aggregate personal income. During the same period the value of owner-occupied housing stock in Arizona increased by 5.2 percent of aggregate personal income. 
Table 3. Changes in Aggregate Values of Equities and Housing Held by Households in Selected States, 1983-99

Percent of state personal income

\begin{tabular}{lcccc}
\hline State & $1983-86$ & $1986-90$ & $1990-95$ & $1995-99$ \\
\hline Arizona & & & & \\
Equities & 14.7 & 9.4 & 20.5 & 28.7 \\
Housing & 5.2 & 5.8 & 7.4 & 8.8 \\
California & & & & \\
Equities & 12.1 & 8.6 & 16.0 & 27.5 \\
Housing & 9.3 & 20.9 & -1.2 & 8.9 \\
Georgia & & & & \\
Equities & 8.2 & 8.9 & 10.4 & 17.4 \\
Housing & 8.1 & 5.1 & 5.5 & 7.8 \\
Illinois & & & & \\
Equities & 13.3 & 10.7 & 15.5 & 29.3 \\
Housing & 4.6 & 7.6 & 5.6 & 3.9 \\
Massachusetts & & & & \\
Equities & 24.5 & 7.3 & 47.5 & 62.0 \\
Housing & 25.7 & 1.9 & 1.5 & 6.8 \\
New York & & & & \\
Equities & 16.2 & 10.6 & 26.2 & 41.5 \\
Housing & 12.9 & 4.9 & 0.6 & 2.6 \\
Texas & & & & \\
Equities & 8.9 & 7.1 & 9.2 & 17.2 \\
Housing & 1.3 & -1.2 & 4.1 & 3.8 \\
Washington & & & & \\
Equities & 14.7 & 10.9 & 17.9 & 28.7 \\
Housing & 4.0 & 13.6 & 7.9 & 9.7 \\
Wisconsin & & & & 38.9 \\
Equities & 13.9 & 8.8 & 28.8 & 5.4 \\
Housing & 3.7 & 5.0 & 5.6 & \\
\hline Sources: Author's calculations based on data from Bureau of Economic Analysis; Federal Reserve, Flow of Funds Accounts; \\
Investment Company Institute; Office of Federal Housing Enterprise Oversight; Bureau of the Census; and Bureau of Labor \\
Statistics.
\end{tabular}

There are several things worthy of note about these data. First, stock market gains far exceeded home value gains in most periods and states. Only in Massachusetts between 1983 and 1986 and in California and Washington state between 1986 and 1990 did home value increases outpace increases in stock holdings. Second, the sheer size of the stock market gains, particularly in the latest period, has been remarkable. In Massachusetts, for example, stock market gains exceeded 60 percent of income between the end of 1995 and the beginning of 1999. Third, there seems to be plenty of independent variation in stock values and housing values. It should be noted that, for most households, the value of their wealth in 
owner-occupied housing still exceeds their stock market wealth, even though aggregate stock market wealth at the beginning of 1999 (\$18 trillion) was double the aggregate value of the owner-occupied housing stock (\$8.9 trillion). ${ }^{10}$

Perhaps no topic in economics has been more widely discussed in the press and in everyday conversation than the wealth effect of the stock market's extraordinary performance. As James Poterba points out, "even if the marginal propensity to consume out of wealth is smaller than the estimates in many macroeconomic models suggest, the sheer magnitude of the wealth accumulation during the last decade still translates into a substantial increase in aggregate consumer spending." 11

But what about the wealth effect from housing? Federal Reserve Board Chairman Alan Greenspan commented on November 2, 1999, that

\begin{abstract}
Although ... the appreciation of stock prices has been vastly greater than that of home prices, most estimates suggest that stock market gains are consumed only gradually, with the level of consumer outlays lifted permanently by around 3 to 4 percent of the wealth generated by the stock market gain. The permanent increase in spending out of housing wealth is somewhat higher, perhaps in the neighborhood of five percent, and is financed in a different manner. ${ }^{12}$
\end{abstract}

Even if Chairman Greenspan's 5 percent figure is correct, a gain of $\$ 1.9$ trillion in housing wealth since 1995 would translate into a spending increase of less than $\$ 100$ billion annually. This would account for over 4 percent of total growth in GDP over the period. Nor is there published evidence that effects from housing are greater than stock market wealth effects. Indeed, a forthcoming paper by myself and Robert Shiller suggests that the effect is about half as large.$^{13}$ Nevertheless, the data presented above provide convincing evidence that, from time to time and place to place, wealth effects deriving from increases in home values are potentially very large indeed. In those regions of the country that have experienced boom-and-bust real estate cycles, home value has been a substantial accelerator on the way up and on the way down.

10. Tracy, Schneider, and Chan (1999).

11. Poterba (2000), p. 108.

12. "Mortgage Markets and Economic Activity," remarks before a conference on mortgage markets and economic activity sponsored by America's Community Bankers, Washington, November 2, 1999, p. 3.

13. Case and Shiller (forthcoming). 
Another question that arises whenever home prices increase significantly faster than inflation is, To what extent are these increases driven by fundamentals as opposed to price inertia? To put it more boldly, does today's real estate market exhibit the characteristics of a bubble that is likely to burst?

Case and Shiller as well as Jim Clayton, among others, provide considerable evidence that housing prices are sometimes driven by inertia and that housing buyers and sellers are often motivated by exuberant expectations. ${ }^{14}$ This was particularly true during the New England boom of 1983-88 and the California boom of 1985-90. Case and Shiller show that the Boston and Los Angeles booms in the late 1980s cannot be explained in terms of the fundamentals. ${ }^{15}$

In contrast, there is little doubt that the U.S. housing market today is being driven by the fundamentals, particularly if one includes the stock market as a fundamental. Employment has been rising at a healthy rate in most metropolitan areas, pushing the unemployment rate below 3 percent in many. Personal income growth has been extraordinary, and the gains in stock market wealth have already been discussed. The pattern of housing price appreciation, both within and across metropolitan areas, also seems to reflect fundamentals. During the recent rise in home prices, studies have found the impact of both demographics and stock market wealth to be significant. ${ }^{16}$ In those metropolitan areas where the demand fundamentals are strong but price appreciation has been weak, there is evidence of expanding supply. ${ }^{17}$

Even when bubbles do burst, or when the fundamentals turn, housing prices rarely fall dramatically. Housing prices are characterized by downward stickiness similar to what has often been observed in the labor market. ${ }^{18}$ Sellers almost always have a firm reservation price or simply resist selling property during recessions. This is not to say that housing prices never fall, but rather that it takes a fairly severe recession to produce the kind of decline in housing value observed in Texas, New England, California, and Alaska during the last decade and a half.

14. Case and Shiller (1988, 1989, 1990); Clayton (1997).

15. Case (1986); Case and Shiller (1994).

16. Case and Mayer (1996); Green (2000).

17. Case Shiller Weiss quarterly forecasts prepared for the Wall Street Journal.

18. Case and Shiller (1988). 
In summary, the recent runup in house prices nationally does not have the characteristics of a price bubble, and even if the economy slows, a precipitous downturn in housing prices is unlikely. If, however, the stock market were to decline sharply and the economy found itself in a severe recession, housing prices would surely fall.

\section{Mortgage Risk}

The savings and loan crisis of the late 1980s and the subsequent massive banking problems in New England and California were largely due to very high mortgage foreclosure rates. The financial system weathered these storms in part because, during any given period, the losses were concentrated in specific regions of the country. A legitimate question is, How would the mortgage market react to a major, nationwide recession? Housing prices are now rising faster than the rate of inflation in every major metropolitan area; they have risen more than 27 percent over the last five years on average; and prices in many metropolitan area submarkets have risen dramatically. The result is very low current levels of default and foreclosure, but heightened risk in the event of a downturn.

Table 4 presents a breakdown of total mortgage debt outstanding by type of property and mortgage holder in 1989 and at the end of 1999. The distribution of mortgage credit across property types changed only slightly over that decade; the largest change was that in the share of one-to-fourfamily housing, which rose modestly from 68.1 percent to 75.2 percent. The ownership of mortgage claims, however, has changed more dramatically. For example, the share held by major financial institutions has fallen from 54.0 percent to 37.6 percent. Almost all of this decline has occurred within the savings and loan industry; commercial banks have held their share. At the same time, the secondary mortgage market has grown, with federal and related agencies now accounting for 41 percent of the total, up from less than 30 percent in 1989. Fannie Mae and Freddie Mac account for the bulk of the increase in agency holdings, with a combined share of just under 30 percent of total outstanding mortgage assets, up from 17.2 percent a decade earlier.

Securitization of mortgages increased meanwhile from 14.8 percent of all mortgage assets in 1989 to 23.2 percent in 1999, and this figure is likely 
Table 4. Mortgage Debt Outstanding in 1989 and 1999

Units as indicated

\begin{tabular}{|c|c|c|c|c|}
\hline \multirow[b]{2}{*}{ Classification } & \multicolumn{2}{|c|}{1989} & \multicolumn{2}{|c|}{1999} \\
\hline & $\begin{array}{l}\text { Billions of } \\
\text { dollars }\end{array}$ & $\begin{array}{l}\text { Percent } \\
\text { of total }\end{array}$ & $\begin{array}{l}\text { Billions of } \\
\text { dollars }\end{array}$ & $\begin{array}{l}\text { Percent } \\
\text { of total }\end{array}$ \\
\hline \multicolumn{5}{|l|}{ By type of property } \\
\hline Nonfarm & $3,505.7$ & 97.8 & $6,079.3$ & 98.4 \\
\hline One-to-four-family houses & $2,443.0$ & 68.1 & $4,647.9$ & 75.2 \\
\hline Multifamily houses & 287.2 & 8.0 & 372.5 & 6.0 \\
\hline Commercial & 775.4 & 21.6 & $1,059.0$ & 17.1 \\
\hline Farm & 80.5 & 2.2 & 101.8 & 1.6 \\
\hline Total & $3,586.1$ & 100.0 & $6,181.1$ & 100.0 \\
\hline \multicolumn{5}{|l|}{ By holder } \\
\hline Major financial institutions & $1,935.2$ & 54.0 & $2,322.0$ & 37.6 \\
\hline Savings institutions & 910.3 & 25.4 & 676.3 & 10.9 \\
\hline Commercial banks & 770.7 & 21.5 & $1,418.5$ & 22.9 \\
\hline Life insurance companies & 254.2 & 7.1 & 227.2 & 3.7 \\
\hline Federal agencies $^{\mathrm{a}}$ & $1,067.3$ & 29.8 & $2,535.4$ & 41.0 \\
\hline Individuals and others & 583.6 & 16.3 & $1,323.7$ & 21.4 \\
\hline Total & $3,586.1$ & 100.0 & $6,181.1$ & 100.0 \\
\hline \multicolumn{5}{|l|}{ Miscellaneous } \\
\hline $\begin{array}{l}\text { Insured by Federal Housing } \\
\text { Administration }\end{array}$ & 282.8 & 7.9 & 450.4 & 7.3 \\
\hline Insured privately & 238.3 & 6.6 & 598.5 & 9.7 \\
\hline $\begin{array}{l}\text { Guaranteed by Veterans } \\
\text { Administration }\end{array}$ & 157.3 & 4.4 & 215.9 & 3.5 \\
\hline $\begin{array}{l}\text { Retained by Fannie Mae and } \\
\text { Freddie Mac }\end{array}$ & 129.4 & 3.6 & 671.1 & 10.9 \\
\hline $\begin{array}{l}\text { Securitized by Fannie Mae and } \\
\text { Freddie Mac }\end{array}$ & 489.4 & 13.6 & $1,111.5$ & 18.0 \\
\hline Multiclass & 112.4 & 3.1 & 621.9 & 10.1 \\
\hline Securitized by private companies & 43.3 & 1.2 & 320.7 & 5.2 \\
\hline Subprime lending & $\ldots$ & $\ldots$ & 472.0 & 7.6 \\
\hline
\end{tabular}

to rise significantly in the next two years. In addition, mortgage risk is more widely acknowledged and explicitly priced. The sum of outstanding mortgages with some form of mortgage insurance or guarantee (from the Federal Housing Administration or the Veterans Administration, or through private mortgage insurance), the risk-tranched securities of Fannie 
Mae and Freddie Mac, and the subprime market has increased from 16 percent to just under 40 percent of total mortgage credit. ${ }^{19}$

Two important stylized facts about the housing and mortgage markets are relevant to the issue of risk. First, as already mentioned, housing prices are sticky downward. That is, during relatively minor downturns, and in particular during downturns driven by high interest rates, sellers hold out for reservation prices that are well above what will clear the market. ${ }^{20} \mathrm{Sec}-$ ond, although default rates certainly rise during recessionary times, actual losses to the financial system do not rise substantially unless and until house prices fall sharply. ${ }^{21}$

In recent years the mortgage market has clearly taken on some of the characteristics of a commodity market. Mortgage credit flows quickly and efficiently to borrowers who are effectively collateralized. Indeed, it also flows quickly and efficiently to many borrowers who are not effectively collateralized: the number of high-loan-to-value and subprime loans has increased sharply. More than half of all outstanding mortgages are sold into the secondary market, most notably to Fannie Mae and Freddie Mac, and well over half of those are ultimately securitized. Half of these agencies' securitizations are classified by risk.

Mortgage holders face four kinds of risk: interest rate risk, prepayment risk, credit risk, and market risk. Clearly, rising interest rates reduce the present value of fixed-interest obligations, but falling interest rates lead to refinancing and prepayment. Both of these risks can be and sometimes are hedged in Treasury futures markets. In today's market environment, with house prices rising in virtually all markets, there is perceived to be very little market risk. As for credit risk, current delinquencies, defaults, foreclosures, and losses are extremely low by historical standards. The result has been record profits for secondary market players, portfolio lenders, and mortgage insurance companies. In addition, the pattern of defaults and delinquencies is well explained by borrower credit scores, which suggests that risk-based pricing has been efficient.

Certainly the mortgage market has become much more sophisticated in managing and pricing interest rate risk, prepayment risk, and credit risk.

19. The subprime market consists of lending to homebuyers who have poor credit or who are taking out mortgages with a high loan-to-value ratio.

20. Case and Shiller (1988).

21. Case and Shiller (1996). 
In addition, those risks are widely distributed across well-capitalized mortgage insurers, holders of mortgage-backed securities, and portfolio lenders. In that sense the industry is better positioned than it was a decade ago to withstand a substantial national downturn. Three concerns remain, however: the absence of any way to fully diversify around or to hedge market risk; the dramatic recent increase in the size and volume of the subprime market; and a substantial exposure of the federal government to catastrophic risk.

By far the bulk of losses suffered by holders, insurers, and guarantors of mortgage paper in the past have been due to regional declines in housing prices. ${ }^{22}$ The simple fact is that delinquencies become defaults and losses only when collateral is insufficient to cover the debt. The losses incurred in Texas, New England, and California between 1985 and 1993 as the result of collateral shortfalls dwarf the losses in the rest of the country due to changes in borrowers' economic circumstances. In the current economic climate, with home prices rising in every region of the country, variations in borrower characteristics such as credit scores explain most of the variation in default and foreclosure. If the housing market were to suffer a 20 percent decline, default rates and losses would far exceed those forecast by the most sophisticated credit-scoring models in the industry.

This worry is to some extent heightened by the dramatic increase in subprime, high-loan-to-value lending of the last few years. Although hard data on the size of the B- and C-rated market are hard to come by, trade publications such as Inside Mortgage Finance, Inside B\&C Lending, and National Mortgage News suggest that about 12 percent of current originations fit the description. A conservative estimate puts the currently serviced portfolio at about $\$ 500$ billion. Seasoned subprime paper exhibits default rates as much as five times higher than traditional high-loan-tovalue mortgages. Although this risk is priced to some extent, these default rates are being observed in an environment of rising home prices. Should prices fall, default rates will rise sharply.

Finally, Congress has become increasingly aware of the explicit or implicit liability of the federal government for losses sustained on portfolios held by Fannie Mae, Freddie Mac, the Government National Mortgage Association (Ginnie Mae), the Federal Housing Administration, and

22. Case and Shiller (1996). 
the Department of Veterans Affairs. Indeed, the government has some exposure to more than half the nation's mortgage portfolio. To be sure, the Treasury is protected by owners' equity, securitizations, mortgage insurance, and OFHEO-imposed risk-based capital requirements (which are based on severe stress tests). Yet the government retains substantial exposure to a sharp drop in real estate prices, and the current debate about the proper role of the government in financial markets is both interesting and important.

\section{The Commercial Real Estate Market}

The late 1980s and early 1990s witnessed a boom-and-bust cycle in commercial real estate markets of worldwide dimensions. From 1988 to 1992, as commercial real estate values were dropping sharply in the northeastern United States, the same thing was happening all over Europe and in many parts of Asia. The losses in value were at times extraordinary. The 1.4-million-square-foot Wang Towers in Lowell, Massachusetts, which sold for $\$ 107$ million in 1998 , had changed hands four years earlier for $\$ 525,000$, or 38 cents a square foot. According to the House Banking Committee's postmortem report on Bank of New England's failure in 1991, the cause of the disaster was the complete collapse of the bank's commercial real estate portfolio. The striking similarity between the cycle experienced in the United States and those in Europe and Asia were highlighted at two large conferences in Paris of bankers, real estate professionals, and scholars. ${ }^{23}$

Clearly, commercial real estate has played an important role in accelerating the recent upswings and downswings of both regional and national economies. ${ }^{24}$ But given current conditions in the U.S. economy, is commercial real estate today a source of vulnerability?

Table 5 presents some very rough estimates of the size of the nation's portfolio of commercial real estate. Total commercial real estate assets are just under $\$ 6$ trillion. Of this total, $\$ 2.3$ trillion represents the approximate value of the nation's 35 million rental housing units, both publicly

23. The first of these, in December 1993, was sponsored by Groupe Caisse des Depôts; the second, in March 1998, was sponsored by Credit Foncier.

24. Browne and Case (1992). 
Table 5. Value of U.S. Commercial Real Estate by Type of Property and Owner, End of 1999

Billions of dollars

\begin{tabular}{lr}
\hline Category & Value \\
\hline Type of property & \\
Office & 1,251 \\
Retail & 1,342 \\
Industrial and manufacturing & 836 \\
Apartments & 2,300 \\
Hotels & 222 \\
Total & 5,951 \\
$\quad$ Excluding apartments & 3,651 \\
Owner & \\
Corporate & 1,682 \\
Commercial mortgages & 1,431 \\
Equity real estate investment trusts & 175 \\
Commercial mortgage-backed securities & 110 \\
Other & 2,553 \\
Total & 5,951 \\
\hline
\end{tabular}

Sources: Author's calculations based on data from Miles and Tolleson (1997); Bureau of the Census, American Housing Survey, 1997; National Association of Real Estate Investment Trusts; Economic Report of the President, February 2000; CB Richard Ellis, Inc.; and F.W. Dodge, Inc.

a. Includes direct household ownership, proprietorships, partnerships and limited partnerships, institutional portfolios, and government.

and privately owned. Of the remainder, 71 percent of value is in the office and retail markets.

Ownership of commercial real estate is diversified. Corporations own more than a quarter of the total and a disproportionate share of the office, retail, and industrial markets. Commercial mortgages held in the portfolios of banks, insurance companies, pension funds, and other institutions total $\$ 1.4$ trillion, of which $\$ 110$ billion has been securitized. Equity real estate investment trusts account for $\$ 175$ billion, not counting leverage. More than 40 percent of the total falls into the category "other," which includes direct household proprietorships, partnerships, limited partnerships, institutional portfolios, and government (only the public housing stock is included in these calculations).

A simple numerical example best illustrates the vulnerability of commercial real estate values to changes in economic conditions. Since the Tax Reform Act of 1986, real estate values can be reasonably approximated with four variables: expected gross rents, vacancies, operating costs, and a "capitalization rate," which is essentially the rate of return a buyer would 
require to justify purchasing the property. Table 6 shows how the four interact. The starting point is gross rent per square foot. Gross rent, for the sake of this illustration, is assumed to be adjusted for incentives offered by landlords, such as free rent or custom buildouts. These are common in weak markets and rare in strong ones. One can approximate a building's value by adjusting expected gross rents for vacancies, subtracting operating costs and taxes, and dividing the result by the capitalization rate. Capitalization rates vary positively with interest rates and with perceived risk.

The first row in table 6 shows such a calculation for an office building that rents for $\$ 35$ per square foot and has a zero vacancy rate. Subtracting taxes and operating costs of $\$ 10$ per square foot leaves an effective rent of $\$ 25$ per square foot. A capitalization rate of 9 percent produces a value of $\$ 27.8$ million for each 100,000 square feet of space.

The second row shows the effect of a 14 percent decrease in gross rent, from $\$ 35$ to $\$ 30$ per square foot. With no changes in vacancy, operating costs, or the capitalization rate, the building's value falls by more than 20 percent, to $\$ 22.2$ million.

The third row shows a further decrease in gross rent (a total decline of 43 percent) similar to the decline in rent experienced in the Boston office market in the late 1980s. Again assuming no change in vacancy, operating costs, or the capitalization rate, value falls by more than 60 percent, to $\$ 11.1$ million. Adding a realistic increase in vacancies (fourth row) and in the perception of risk on the part of potential buyers, resulting in a higher capitalization rate (last row), produces a loss in value of more than 75 percent.

These kinds of losses were actually experienced in some real estate markets in the 1990s. Several factors contributed to the extent of the damage. Very low vacancy rates in the early 1980s and optimism about services sector employment contributed to a substantial building boom. This was fueled by enthusiastic financial markets both nationally and locally. The deregulated banking sector acquired a strong appetite for asset-backed lending. Modern portfolio theory, then finding its way into the asset allocation formulas of pension funds and insurance companies, pointed heavily in the direction of real estate for diversification purposes. ${ }^{25}$ The Tax Reform Act of 1986 lowered marginal tax rates, repealed the capital gains exclusion, altered passive loss rules, and dramatically lengthened the 


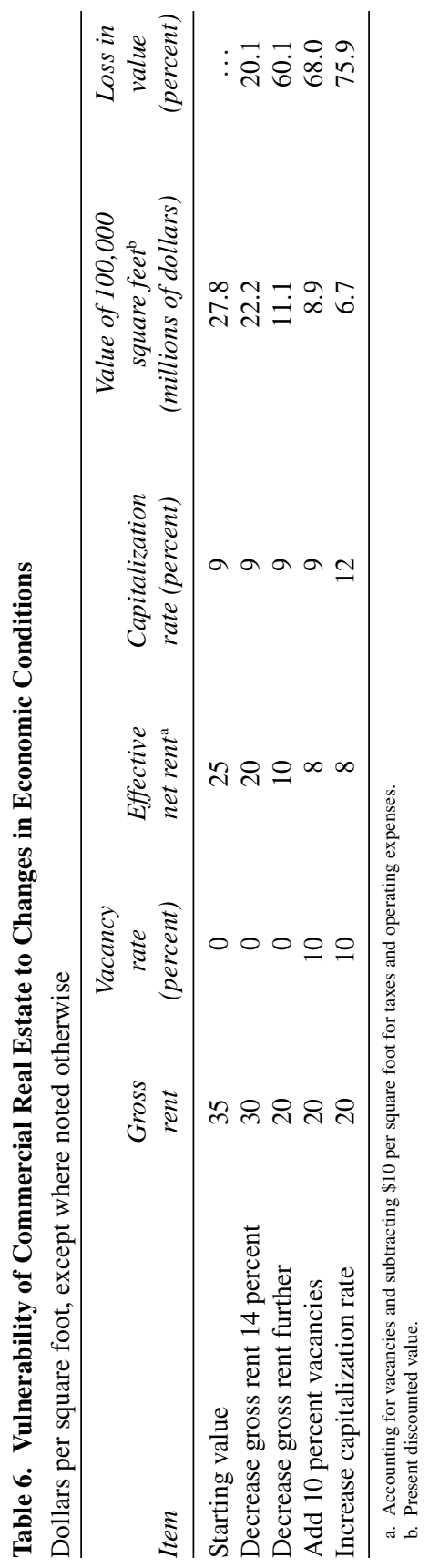


depreciable lives of assets. These tax changes interacted with the previous favorable provisions of the Economic Recovery Tax Act of 1981 to drastically alter the tax landscape for real estate. Of course, the late 1980s and early 1990s witnessed sharp regional declines in employment and a national recession, producing substantial job losses and office vacancies.

The cyclicality of commercial real estate markets is due in part to very long lags between the planning and the production of new space. Any office building must be planned, designed, presented to the community, and zoned, and permits must be obtained. Development of a building, from the beginning of its planning to the time it opens for business, can take anywhere from five to ten years. The economic environment within which expectations of future rents are formed can be very different from that into which the finished building emerges. Clearly, this is true of all production, but an overstock of automobiles, for example, can be reduced simply by curtailing production in the next period, or by shipping the excess inventory to markets with stronger demand. An overstock of real estate assets, in contrast, merely gathers dust, while debt service payments continue.

Current conditions in commercial real estate markets are very strong. The average vacancy rate for the nation's metropolitan areas as of the first quarter of 2000 was 9 percent, compared with 20 percent a decade ago. ${ }^{26}$ Some markets are extremely tight. The vacancy rate in the San Francisco metropolitan area is less than 1 percent, and that in downtown Manhattan is 2.4 percent. ${ }^{27}$ As a result, real rents are at all-time highs. San Francisco leads the way, with asking rents in excess of $\$ 80$ per square foot per year. The average rent for class A space in Boston is approaching $\$ 65$ a square foot, and some buildings there have leased space for as much as $\$ 75$ a square foot. Although no public data on effective capitalization rates are available, some large transactions have been closed with capitalization rates between 6 and 7 percent. The unavoidable conclusion is that the figures in table 5 are as high as they have ever been.

Does this mean the commercial real estate market is vulnerable to the inevitable economic downturn? The answer appears to be yes and no. First of all, many of the conditions that led to the real estate problems of the

26. CB Richard Ellis, Office Vacancy Index, 1st quarter 2000.

27. Press reports, however, indicate that rents for as much as 20 percent of the office stock in San Francisco are being paid with dot-com stock warrants in lieu of cash. 
1980s are absent today. The rate of new construction has been fairly modest around the country. In the first quarter of 2000 only 18 million square feet of new office space came online in the metropolitan portion of the office market, about a 0.6 percent increase in the existing stock. ${ }^{28}$ Over the rest of 2000, construction activity is forecast to continue to slow in response to rising investor caution and higher interest rates. Given the experience of the early 1990s, financial institutions, pension funds, and insurance companies have become significantly more cautious in their real estate lending practices. Finally, the basic tax treatment of real estate has not changed dramatically since 1986.

Clearly, however, a national recession would have a significant impact on the value of commercial real estate portfolios. One can see this by estimating the impact of a significant recession on office occupancy rates and rents. A downturn that reduced office employment by 1.8 million workers would cause as much as 270 million square feet, or an additional $4 \frac{1}{2}$ percent of the roughly 6 billion square feet of office space nationwide, to become vacant. If rents fell 15 percent in response (a reasonable guess), and capitalization rates rose from 8 percent to 9 percent, the value of the nation's office stock would fall by about 37 percent, to $\$ 792$ billion, for a loss of $\$ 460$ billion. Assuming comparable losses in retail, industrial, and hotel values, the total loss could exceed $\$ 1.3$ trillion.

Is this a big number or a small one? It is clearly large as a percentage of the nation's real estate portfolio, but it is relatively small as a fraction of national wealth, especially in the wake of the dramatic appreciation in the stock market since 1995. If stock market wealth is now $\$ 18$ trillion, the entire hypothetical loss in real estate would be the equivalent of a 7 percent stock market correction-roughly a 245-point drop in the NASDAQ index and a 735-point drop in the Dow Jones Industrial Average from those indexes' November 2000 levels.

In summary, commercial real estate is a significant part of the nation's portfolio of assets. The market today is as healthy as it is ever been, with no clear signs of overbuilding. Although commercial real estate markets remain inherently volatile, many of the destabilizing factors of the 1980s are gone. Certainly a significant recession would create major losses in commercial real estate, but the diversification of ownership and the stable capital base of market participants would spread the impact broadly.

28. CB Richard Ellis, Office Vacancy Index, 1st quarter 2000. 


\section{Distributional Effects of Home Price Appreciation and Rent Inflation}

For the two-thirds of American households who are owner-occupants, the real rise in home prices that the United States has been experiencing for the past five years is unambiguously good. Most homeowners have earned leveraged returns comparable, in percentage terms, to those on the stock market, building substantial equity. Meanwhile their out-of-pocket costs are protected by fixed-rate mortgages or slowly adjusting adjustablerate mortgages. In fact, most homeowners face constantly declining real house payments.

It can, of course, be argued that a rise in housing prices makes an owner no better or worse off than before: although the household's assets have increased, at the same time the price of housing services has increased to offset that gain. The budget constraint has shifted outward, but the increase in the price of housing services has shifted it back, resulting in only a modest gain in welfare. For example, a homeowner who has lived for some years in Palo Alto, California, has probably reaped an enormous capital gain, but that homeowner would find it very expensive to buy another house in Palo Alto. However, such a homeowner can be considered better off if the Palo Alto market has inflated more than other markets where the homeowner might be willing to move. He or she could decide to retire to Albuquerque and live in a mansion, for example.

But a more important point is that homeowners in almost all regions are much better off than renters in the same market. Home price appreciation and rising rents are unambiguously bad for the one-third of the population that pay rent. In most metropolitan areas, rents have risen faster than other prices and incomes, and the potential for homeownership is diminished. Although there is substantial variation across metropolitan areas, the boom of the late 1990s has clearly widened the real income distribution between owners and renters.

Calculating the total return to an investment in housing is clearly a complicated matter, which must take into account appreciation, imputed rent, tax considerations, opportunity costs, maintenance and repair, and depreciation. But the variance in these returns over time is driven by appreciation. Table 7 presents some calculations that illustrate the benefits that have accrued to owners in the current market. The first column of the table shows median home values in the Boston, Chicago, and Los Angeles met- 
Table 7. Increases in Housing Equity by Income of Homeowner, 1995-98

Dollars

\begin{tabular}{|c|c|c|c|}
\hline Decile or quintile by income & $\begin{array}{l}\text { Value of median } \\
\text { house, } 1995\end{array}$ & $\begin{array}{c}\text { Equity in } \\
\text { house, } 1995^{\text {a }}\end{array}$ & $\begin{array}{c}\text { Equity in } \\
\text { house, } 1998\end{array}$ \\
\hline \multicolumn{4}{|l|}{ Boston } \\
\hline Top decile & 419,855 & 83,971 & 171,381 \\
\hline First quintile & 313,127 & 62,625 & 125,487 \\
\hline Second quintile & 204,355 & 40,871 & 77,536 \\
\hline Third quintile & 165,603 & 33,121 & 60,840 \\
\hline Fourth quintile & 124,864 & 24,973 & 46,792 \\
\hline Fifth quintile & 74,513 & 14,903 & 27,792 \\
\hline Bottom decile & 53,059 & 10,612 & 18,417 \\
\hline \multicolumn{4}{|l|}{ Chicago } \\
\hline Top decile & 378,240 & 75,648 & 112,048 \\
\hline First quintile & 279,070 & 55,814 & 81,153 \\
\hline Second quintile & 181,347 & 36,269 & 51,749 \\
\hline Third quintile & 135,740 & 27,148 & 40,599 \\
\hline Fourth quintile & 99,667 & 19,933 & 32,620 \\
\hline Fifth quintile & 60,241 & 12,048 & 23,821 \\
\hline Bottom decile & 42,222 & 8,444 & 17,777 \\
\hline \multicolumn{4}{|l|}{ Los Angeles } \\
\hline Top decile & 449,223 & 89,845 & 176,610 \\
\hline First quintile & 397,409 & 79,482 & 146,869 \\
\hline Second quintile & 245,690 & 49,138 & 71,218 \\
\hline Third quintile & 192,857 & 38,571 & 58,073 \\
\hline Fourth quintile & 158,014 & 31,603 & 46,909 \\
\hline Fifth quintile & 103,892 & 20,778 & 25,660 \\
\hline Bottom decile & 75,200 & 15,040 & 18,890 \\
\hline
\end{tabular}

ropolitan areas for families at different points in the distribution of income for owner-occupants; these values are derived from cross tabulations of home value and income from the 1993 and 1995 American Housing Surveys. The second column is simply 20 percent of the first column, or the initial equity of a buyer of the median home in each category, assuming an 80 percent loan-to-value mortgage. The third column uses zip-codelevel weighted repeat sales indexes from Case Shiller Weiss, Inc. to inflate home values and recompute equity at the end of 1998 . The index used to inflate home values for the top decile is a weighted average of the indexes for the top 10 percent of zip codes ranked by income in 1990, and so forth. 
Looking at appreciation alone shows that leveraged investments in housing have produced strong nominal rates of return for both lower- and higher-income households. Those rates of return have continued into early 2000 and are comparable to the recent stock market returns. For example, the rate of return to a bottom-decile homebuyer in Chicago was 28 percent annually between 1995 and the end of 1998. High-income buyers did better than low-income buyers in Boston (27 percent a year versus 20 percent) and in Los Angeles ( 25 percent versus 8 percent), whereas in Chicago low-end buyers did better (28 percent versus 14 percent). It should be noted that the 8 percent returns for low-income buyers in Los Angeles would produce "negative leverage" against appreciation if financed with a mortgage at a rate above 8 percent. Nationwide, if one uses the OFHEO national index and assumes 80 percent leverage, appreciation alone generated compound returns of 18.8 percent annually between the first quarter of 1995 and the first quarter of 2000.

At the same time, real rents are rising. Notwithstanding considerable variation across states and metropolitan areas, the "rent of primary residence" component of the consumer price index has risen 14.3 percent nationally since 1995 , compared with 11.4 percent for prices in general. Increases in some metropolitan areas have been significantly greater. For example, over the same period, rents in the Boston metropolitan area are up 24.7 percent. At the same time, figures from the Current Population Survey show that the mean income received by the lowest quintile increased 10.4 percent between 1995 and the end of 1998 (the most recent date for which data are available). Meanwhile the mean income of the highest quintile increased 16.6 percent.

The combination of increasing assets and declining real out-of-pocket payments for owners and rising real rents for renters has clearly widened the already significant gap between owners and renters in the distribution of income. According to the 1997 American Housing Survey, the median income of owner-occupant households was $\$ 43,840$ in that year. The median income of renter households was $\$ 22,834$, just about half the figure for owners. Figure 5 shows the distribution of income for owner and renter households.

In those metropolitan areas that have experienced the highest rates of appreciation in housing prices, there is increasing interaction between the rental and ownership markets. In cities like San Francisco, Boston, and New York, demand pressure in the rental market combined with supply 


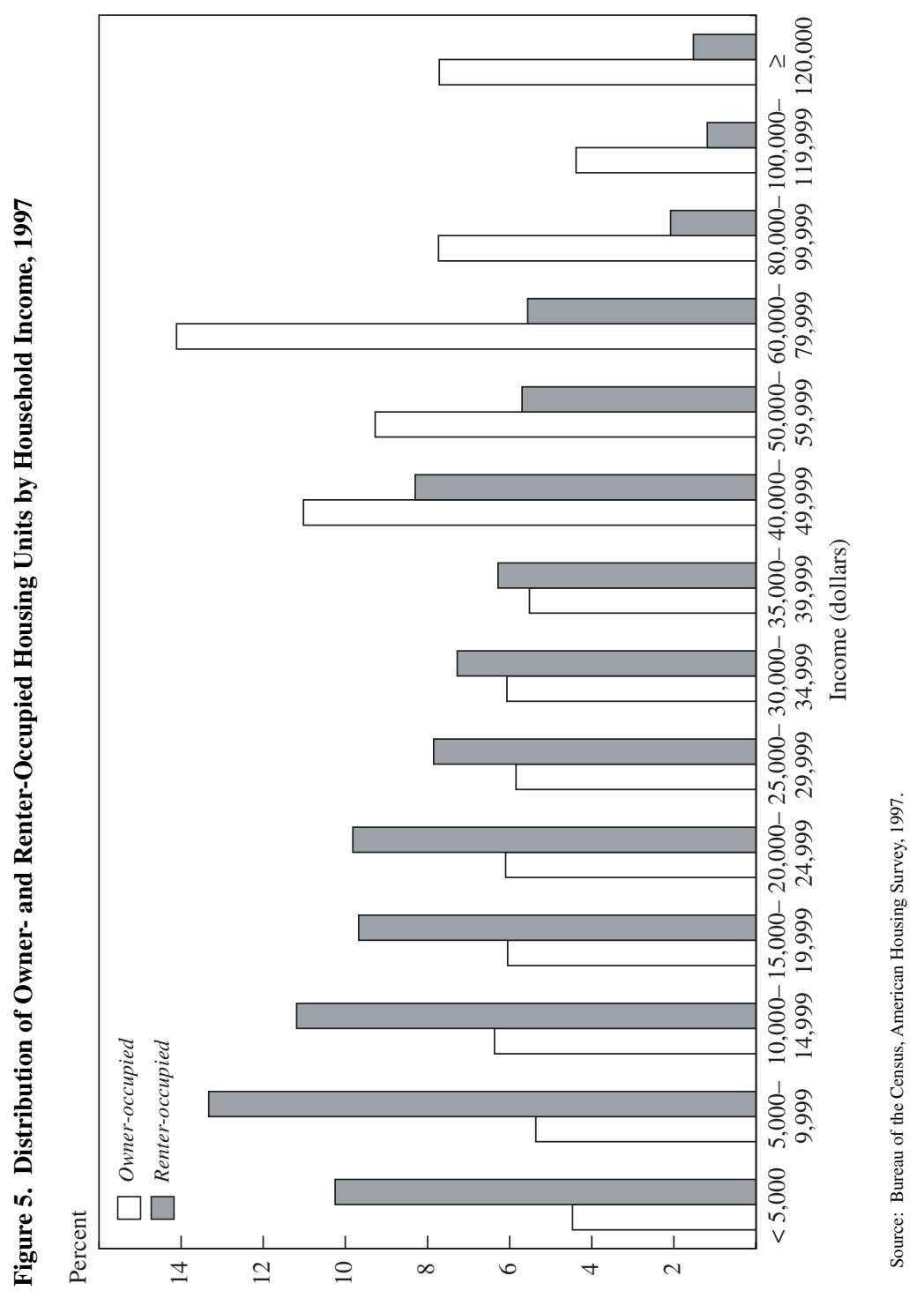


restrictions are leading to enormous waiting lists for rental assistance and public housing, in the midst of the longest period of prosperity in the nation's history.

\section{Conclusions}

This paper has explored several dimensions of the relationship between the real estate market and macroeconomic performance. It is motivated by the extraordinary strength of national real estate markets today and the powerful role that real estate has played in regional business cycles over the years.

This paper's examination of the housing market focused on the owneroccupied portion of that market. This market is large, appreciation has been rapid, and capital gains to owners have been significant. Yet even if the more extreme estimates of the wealth effects of this rise were true, housing inflation would explain only a small portion of the expansion of consumption since 1995. In addition, inflation of housing prices during the late 1990s seems to have been driven by the fundamentals rather than by speculation and price inertia as has been the case in regional markets in the past. Moreover, aggregate housing market appreciation is dwarfed by that of the stock market during the past five years. ${ }^{29}$ Finally, because house prices are sticky downward and characterized by inertia, it is unlikely that an economic downturn would lead to a precipitous decline in home values.

This paper's examination of the $\$ 6.2$ trillion mortgage market focused on residential mortgages and found that this market has become much more sophisticated and efficient in recent years and currently is very healthy. In addition, mortgage risk is widely distributed across wellcapitalized mortgage insurers, holders of mortgage-backed securities, and portfolio lenders. Although a number of concerns remain, including the inability of holders to diversify around or hedge market risk, and the rise of the risky subprime market, the industry is better positioned than it was a decade ago to withstand a substantial national downturn.

29. The paper has not explored the interaction between the stock market and housing market. Preliminary results in a forthcoming paper by Case and Shiller suggest that the stock market "causes" price movements in the housing market, in a statistical (Granger) sense, regionally and across time, but not vice versa. 
The aggregate value of commercial real estate markets, meanwhile, is as high as it has been in history, and the volatile nature of this category of real estate makes it vulnerable in the event of a downturn. Mitigating this vulnerability, however, are a relatively slow pace of construction activity and a fairly diversified and well-capitalized ownership base. Here, too, likely potential losses are small relative to the increase in the capitalization of the stock market over the last five years.

Finally, the paper points out that rising real house prices, rising real rents, and stagnant income at the bottom of the income distribution have significantly widened the already large real income gap between owners and renters.

An important question, not addressed in this paper, is to what extent the current strength in real estate and mortgage markets is the result, directly or indirectly, of the extraordinary performance of the stock market. If the link is strong, a precipitous decline in the stock market could trigger major losses in real estate and mortgage markets. What now appear to be healthy and relatively well risk-managed and diversified markets could all shed value simultaneously. 


\section{Comments and Discussion}

Edward L. Glaeser: Karl Case has written an interesting and thorough paper on an enormously broad question. By and large, he comes up with answers that I agree with. Although individual housing markets may look like bubbles, probably only a few truly are. The connection between housing wealth and spending is probably pretty small. If real estate does play a big role in the banking industry, that role comes through the banking sector. In this discussion, therefore, I will try to organize the hypothesized links between housing and the macroeconomy and talk about each.

First, there is clearly a connection between aggregate economic activity and the construction sector. This force cannot be large in the aggregate, however-construction, after all, is not a huge sector of the national economy-but there is no question that local labor markets have often been substantially buoyed by construction employment. There are some interesting questions about this sector, however, the answers to which will influence our thinking about the cyclical importance of construction. To what extent are construction markets national or local? To what extent can construction workers freely move into and out of the sector? Just how big are the shifts in this sector over the business cycle? A future paper could usefully concentrate on these issues. But it is hard to believe that construction will ever be big enough to drive much in the macroeconomy.

A second connection involves the role of real estate as wealth and the marginal propensity to consume out of real estate. Case's focus on this connection is motivated, in part, by a claim by Federal Reserve chairman Alan Greenspan that the marginal propensity to consume out of real estate wealth is about 5 percent. This somewhat inscrutable, and unsupported, claim seems awfully hard to accept, given what we know about the basic 
economics of housing markets. Indeed, I take the view that changes in real estate prices (holding the stock of housing constant) have basically no effect on aggregate wealth. As such, this entire discussion seems a little silly.

A house is both an asset and a necessary outlay. If people lived forever and planned to reside in the same community forever, changes in local housing prices would have very little effect on their net welfare. If housing prices double, they then have twice as much wealth, but their cost of living has risen by exactly the same amount. When my house rises in value, that may make me feel wealthier, but since I still need to consume housing there in the future, there is no sense in which I am actually any richer. And because housing prices are themselves a major component of the cost of living (indeed, they are the primary source of geographic differences in the cost of living), one cannot think of changes in housing costs in the same way as changes in the value of a stock market portfolio.

The classic economic approach to utility gains from changes in house prices suggests that utility rises for homeowners if housing prices rise but also if they fall (a lesson I learned from Edward Lazear). The argument is that whether house prices rise or fall, individuals can always continue to consume their initial consumption bundle. Thus, they cannot have lost utility. However, if housing prices fall, they can, in principle, consume more housing and thus raise their living standard. If housing prices rise, they can consume less housing and still raise their living standard. However, this change in utility will be far less than that which would come about from a cash transfer to the homeowner equal to the price appreciation of the house. Thus current homeowners might realize a gain in utility from the price increase, but this gain comes from the ability to reoptimize their consumption bundle with different prices. It will not have the same magnitude as a rise in stock prices.

The arguments just advanced assume infinitely lived consumers who own their houses outright (or at least are not highly leveraged) and plan to stay in them. Naturally, the situation changes when we consider consumers who are planning to move. Consider two hypothetical assistant professors at Stanford, both of whom bought 1,800-square-foot bungalows in 1995 for $\$ 250,000$. Assume, for simplicity, that both paid cash. Both bungalows are now worth $\$ 2.5$ million. (If this is an overstatement of the rise in the Palo Alto real estate market, it is not by much.) Now assume that one of these professors has just been turned down for tenure and is going 
to the University of Rochester. This professor has just become much richer and will live quite well on his housing wealth. The other has been promoted and will stay in Palo Alto. She is probably made worse off by the housing price appreciation. She would like to trade up to a 3,000-squarefoot home, but such a home will be much more expensive than she can afford. In short, the mobile professor gains from his housing price appreciation whereas the immobile professor does not.

Does this mean that a significant fraction of U.S. homeowners will benefit from housing price appreciation? Yes, certainly those with short time horizons in certain locales will see real gains. But the existence of a housing market means that, just as these people are selling, others will be buying, and the rise in housing prices makes them equally worse off. Thus, on net, the wealth of the United States has not increased.

Leveraging clearly exacerbates these effects. If the two Stanford professors each put only $\$ 25,000$ down on their houses, the one who is leaving for Rochester will realize a 1,000 percent return on his investment over the five years. The one who stays at Stanford receives the same, although unrealized, gain. But this does not change the fact that she is made worse off by the housing price increase, nor does it change the fact that the person who buys the house from the Rochester-bound professor will also be worse off. Leverage is important to the housing market in many ways, but it does not alter the basic argument that national wealth is close to neutral with respect to changes in housing prices, because rising prices increase costs that wholly offset the increase in wealth. Some individuals will benefit, and others will equally lose.

A third channel that connects real estate prices and the macroeconomy is the banking sector. Most banks hold massive real estate portfoliosmortgage lending, after all, is a large part of what banks do. It is a commonly accepted stylized fact (which, like many other stylized facts, may not be entirely true) that banking crises are always linked to overlending in real estate. By overlending, I mean lending that looks excessive ex post, not ex ante. Of course, it is possible that market failures in the banking sector (perhaps due to deposit insurance) mean that this lending was socially inefficient ex ante as well. As banks have increasingly been able to securitize mortgages, many of the worst problems in this area may disappear. A common type of banking crisis is that caused by rising interest rates. Higher interest rates cause problems for banks because many of their assets are long-term, fixed-interest mortgages whereas their liabilities are 
largely short-term deposits, rates on which may change. As more mortgages are securitized, this mismatch tends to disappear, and banks function more as pure middlemen.

The final channel through which real estate prices affect the macroeconomy is through their role in allocating workers and firms across geographic space. The huge differences in wages between places like New York and Mississippi suggest that there are massive differences across space in the marginal productivity of workers and firms. A benchmark figure is that the wage gap between workers in metropolitan areas surrounding large cities (those with over 500,000 people) and those in nonmetropolitan areas is about 30 percent. Naturally, this means that moving people to more productive places could have a large effect on national productivity. These effects grow even larger if the rate of innovation is higher in dense urban areas.

The primary force that prevents people from moving into high-wage areas is high rents. Indeed, in equilibrium, if real utilities are to be equalized across space, high wages must compensate people for higher rents in more productive areas. (In principle, lower levels of amenities in those areas can also serve as an equilibrating device.) Within these highproductivity areas, some workers do live in cheaper housing far from the employment centers, but these workers can be said to be paying in the time costs of commuting.

This view of the world suggests that workers do not freely flow to highproductivity areas like New York City or Silicon Valley because of high prices in those areas. In principle, if it were possible to reduce housing costs in these regions, employment would move there from places where productivity is lower, and the result would be a significant improvement in GDP. Indeed, many authors (myself included) think that the urbanization of the U.S. population in the past 200 years was one of the major forces leading to higher levels of income and faster growth rates.

This reasoning leads me to the only really policy-related issue of this discussion. Is it possible, and is it desirable, for the government to adopt policies that would lower housing costs in regions where they are high? Standard economic analysis would suggest that land is a normal commodity and that movements in its price reflect standard market forces with which it is foolish to meddle. It is presumably true that production of certain goods would improve if the government reduced the price of steel, but it does not follow that the government should subsidize steel production. 
In some cases this analogy with steel might be apt, but in several of the country's hottest real estate markets, high housing prices have much more to do with government policies than with the market. Silicon Valley is not short on land. Indeed, there are millions of acres of undeveloped land right in the heart of the Bay Area. This land is undeveloped because of restrictions on development created primarily by zoning regulations. New York City, in contrast, has little undeveloped land, but much of that land has been developed at inefficiently low density levels. These areas could be razed and rebuilt, if the zoning environment were more favorable. It is hard to look at real estate markets and not conclude that almost every extreme case of high housing prices originates in restrictions on development.

There may be good reasons for certain types of zoning. After all, zoning is meant to correct for externalities that we believe exist. However, zoning in many places has much more to do with increasing property values for existing residents, by restricting supply, than with accomplishing anything socially efficient. Moreover, it is always the case that current residents fail to internalize any of the benefits that would accrue to current nonresidents from new construction. It is time to rethink the entire system and ask whether we can move to a fee-based system, where developers pay reasonably assessed externality-based fees for new construction.

This type of radical innovation is possible. In the 1920s modern zoning regulations were enacted in a massive wave of policy innovation that swept the country. Similarly today, if the states and the federal government exerted sufficient pressure, local governments could move to more rational zoning rules. As I think about real estate prices and the macroeconomy, I come to the view that lowering prices through zoning reform in highproductivity areas is the most important area for new work.

Jonathan A. Parker: This paper by Karl Case describes recent developments in the prices of both residential and commercial real estate and contrasts these movements with those observed in the late 1980s. The most noticeable trend is that of housing prices. In some areas of the country, housing prices have reached what many of us on junior faculty salaries perceive as extremely high levels. A less noticed phenomenon is that corporate real estate prices have soared in much the same geographic areas. In the late 1980s the real estate market also boomed; then, with the first signs of recession, it collapsed. A credible argument can be made 
that this collapse was an important contributor to regional economic downturns in the early 1990s.

My comments will focus on four questions about the current real estate boom and its parallels with the previous boom-bust cycle. First, what are the main issues at stake, and why should we care particularly about real estate? Second, what are the main lessons that we can take from this paper, and which of its findings are open to question? Third, how can we better understand the links between the real estate market and regional and national economic activity? Finally, is the real estate market really less fragile today than at the end of the last expansion?

Residential and commercial real estate account for a substantial share of both household wealth and the capital stock in the United States. On average over the postwar period, one-third of household net worth has been real estate; this number is a little lower at present because recent increases in the value of corporate equity have significantly exceeded increases in real estate values. Real estate also typically accounts for about half the net market (replacement) value of nonfarm, nonfinancial corporate business assets. Thus, large changes in the value of these assets will cause significant changes in demand for investment and consumption. I make this comment with caveats. Reverse causation is likely: stronger demand for these assets surely increases their prices. Also, an increase in the price of housing represents an increase in the cost of consuming housing, so that an increase in demand for other items of consumption does not automatically follow. However, there are good theoretical and empirical reasons to believe that increases in real estate prices do increase demand for consumption and investment. I will return to both these caveats.

The real estate market not only is large but also plays a special role in both the amplification and the propagation of shocks to the economy. If firms use real estate as collateral for borrowing and find other channels of raising funds more costly if not inaccessible, then a decline in the value of real estate will reduce the value of available collateral, and with it the availability of funds for investment, and thus reduce investment itself. That is, real estate bears an important role in allowing firms to raise funds. In good times, increases in real estate prices further increase investment. In bad times, declines in real estate prices can amplify recessions. Similar arguments can be made about housing and consumption demand for households seeking to borrow. 
Real estate plays a special role in another way. Because a significant share of bank portfolios consists of mortgages, declines in real estate prices that lead to mortgage defaults deplete bank capital. Because banks are an important source of financing for investment, particularly for small firms, a decline in real estate values causes a reduction in investment by reducing the supply of bank credit.

In summary, this paper and topic are of particular importance because of the special role that real estate plays in economic activity, disproportionate to its magnitude. Through providing collateral for loans and through its importance for bank capital requirements, real estate prices amplify and propagate shocks to the economy. The paper does not highlight them, but I encourage the reader to think about the paper's findings in terms of these channels.

Case's first main conclusion is that real estate prices have risen by significantly less in the current expansion than they did in the previous one. Housing prices have risen about 25 percent over the last five years. The paper takes as a working hypothesis that the decline in real estate prices was an important amplifying mechanism in several regions during the 1991 recession. I suspect this is correct. The consensus view of the 1991 recession as a "credit crunch" is consistent with real estate playing an important amplifying role. Thus the question that one faces is, if real estate prices contributed to instability or volatility in the late 1980s and early 1990s, can they do so again now? I read the evidence of the paper as saying that the answer is probably yes, but that the situation is not as fragile as it was in the late 1980s.

Second, Case also points out that the recent increases in real estate prices are significantly smaller than the increases in stock prices over the same period. During the same five years that housing prices were rising 4.9 percent a year in nominal terms, the S\&P 500 index gained 25 percent a year. One might then argue that one should be more concerned, if one is the type to be concerned, about the stock market than about the real estate market. But this would be to ignore the special roles of real estate just discussed. Anyone who fears a market crash should be concerned about high real estate prices because of the role that real estate plays in financing investment and on bank balance sheets.

Third, Case demonstrates that the recent increases in real estate prices are not uniformly distributed across the population or regions of the United States. He shows, somewhat surprisingly, that despite considerable 
regional variation, declines in house prices are infrequent and relatively small (relative, that is, to declines in the stock market). To take one of the most extreme examples, in Massachusetts at the end of the 1980s housing prices declined over three years, and the decline eliminated 25 percent of the gain that had occurred over the previous five years. In other words, in this extreme case, the decline in prices was only a quarter of the preceding increase, yet the effect of the decline, at least by some accounts, seems to have been very large. In the absence of other large regional shocks, the bankruptcy of the largest regional bank in New England appears to be evidence of real estate as a channel of amplification.

The fourth main conclusion of the paper is that the implied increases in consumption spurred by the recent housing boom are not large. Case bases this argument on an estimated marginal propensity to consume out of housing wealth of 5 percent, a number attributed to Alan Greenspan. Multiplying this by the increase in housing wealth leads to a number quite small in relation to aggregate consumption.

Without seeking to quarrel with the Federal Reserve chairman, I would like to begin my discussion of these four points by discussing the consumption effects of an increase in housing prices. I suspect that, given real estate's argued amplification effects, the impact of real estate prices could be large. Think first about the simplest case, namely, an exogenous increase in house prices. Such an increase would lead to gains that are not evenly distributed across households. But if all households chose to spend all of those gains on housing, total wealth less the present value of housing consumption costs would be unchanged, and so demand for other consumption would remain unchanged. There are three reasons, however, to think that the response of nonhousing consumption would be well above zero. First, the increase in the price of housing is likely to cause households to reduce their demand for housing. This would reduce the original price increase and lead to less new construction. The increase in wealth would be less than it would have been absent a behavioral response, but whatever wealth increase there is would lead to other forms of consumption. Second, households differ in their marginal propensities to consume. For young households that own houses and have large amounts of liquid wealth, the increase in house prices will be roughly balanced by increases in the cost of housing. But for older households, an increase in the price of the house they own increases their wealth more than it does the cost of housing consumption over their remaining lives, and for liquidity- 
constrained households, such an increase allows them to borrow more. Both effects increase the consumption of nonhousing wealth. Third, there is empirical support for a significant propensity to consume out of housing wealth on average. ${ }^{1}$

There are also reasons to believe that the direct impact of changes in housing wealth on consumption could be of an order of magnitude similar to that of the recent stock market boom. More households own homes than own stocks, which implies that increases in housing values are more evenly distributed across the population than are stock returns. The propensity to consume out of wealth, at least in the short run, is decreasing in wealth. In other words, the rich save more. ${ }^{2}$ Coupled with the fact that the returns to housing wealth are more evenly distributed across the population, this implies that changes in housing wealth might, in the short run, be more important for consumption demand than changes in stock market wealth. The structure of financial markets today also implies that households have reasonably easy access to housing wealth through second mortgages and home equity loans. Liquidity-constrained households and households for whom precautionary saving is important may not be able to borrow against increases in their pension wealth, but they may be able to increase their borrowing and their consumption when the value of their house rises. Finally, the well-established equity premium puzzle is due to the fact that consumption does not respond much to stock market wealth. In summary, it is entirely possible that increasing house prices are more important for consumption demand in the short run than one would be led to believe from housing's share of wealth and consumption and from recent returns on housing and the stock market.

Consistent with this idea, the ratio of consumption to GDP in the United States increased during the late 1980s, when housing prices rose rapidly, and did not increase in the late 1990s, when housing price increases were more restrained but stock returns were enormous. ${ }^{3}$

Although housing prices are indeed an important determinant of consumption demand, consumption demand is also an important determinant of housing prices. The flip side of the increase in the consumption share of output in the 1980s is that a significant share of that increase consists of

1. See, for example, Hurst (1998) and Skinner (1996).

2. See, for example, Gentry and Hubbard (2000), Parker (1999), Quadrini (1999), Carroll (2000), and Dynan, Skinner, and Zeldes (2000).

3. See Parker (1999). 
spending on housing services. The ratio of consumption to GDP rose 5 percentage points from 1980 to 2000, 1.4 percentage points of which represent increases in the consumption of housing services. So, if consumption demand increases house prices, and house prices increase consumption demand, what are we to make of the current runup in prices and the fact that the increase seems less than in the last expansion?

Several observable phenomena are candidates for explaining why increases in housing prices in this expansion have been less than in the previous expansion. The main ones are the factors other than the price of a house that determine the effective cost of homeownership, namely, the real interest rate, the inflation rate, and the tax deductibility of nominal interest payments on mortgages. The most important change in these factors since the mid-1980s is that brought about by the 1986 tax reform, which removed the tax deductibility of interest on consumer debt except for mortgage debt. This reform gave households an incentive to decrease their consumer debt and to increase leverage in housing after 1986. This move to favoring housing consumption over other forms of consumption, conditional on wanting to hold enough secured debt, should have increased demand for housing and encouraged leverage. I think that this may well explain much of the difference in behavior of real estate prices between the previous and the current expansions. In addition, whereas from 1995 to 1999 inflation fell slightly, increasing the effective cost of homeownership, from 1985 to 1989 inflation was not stable but showed no consistent trend, first falling and then rising. The real interest rate fell during the second half of the 1980s and rose during the second half of the 1990s. All of these factors are consistent with a smaller increase in house prices in this boom than in the last.

Another observable factor that may be holding down the demand for housing is the changing age structure of the population. Gregory Mankiw and David Weil pointed out that the changing age distribution of the population, coupled with the typical pattern of demand for housing over the life cycle, implies a declining demand for houses starting in $1990 .{ }^{4}$ The logic is simply that the baby-boom generation is starting to retire and that retirement has historically led households to reduce their consumption of housing. Although prices have not declined as predicted, we are observing a smaller increase in house prices in this expansion than in the previ-

4. Mankiw and Weil (1989). 
ous one. I remain skeptical of any important role for the age structure, however. Empirical work has found only a small role for changes in the age distribution in determining consumption demand. ${ }^{5}$

A final observable factor is the continuing development of financial instruments that allow households to borrow a larger fraction of their home's value and to do so more quickly and at lower cost than in the past. Home equity loans and second mortgages certainly have steadily become more common, and they may, by making housing wealth more liquid, increase the demand for housing. I do not know of any evidence that suggests that this effect might be less strong in the current expansion than in the last. Nor is it obvious that this is not a reaction to the tax incentives created in 1986.

I can only speculate which of these factors are actually at work. But the returns to a better understanding of the real estate market are large, and I encourage the author to pursue the causes of the differences that he uncovers.

Now let me return to the issue of distribution by focusing on regional variations in real estate prices. There is much to learn from regional variations in real estate cycles, and I simply wish to highlight the important issues at stake. First note that the role of real estate as an amplifier of shocks varies significantly with the distribution of real estate debt and mortgage holding. Because firms that are collateral constrained react more strongly than other firms to changes in the price of collateral, the impact of a macroeconomic shock in a region is jointly determined by the extent of firm indebtedness and the magnitude of the movement in the price of real estate.

Now consider a region in which the economy is booming. A regional shortage in housing or corporate real estate may act as a significant barrier to growth. The same increases in real estate prices that are slowing growth, however, may help other firms grow by increasing the value of their collateral. Finally, increased borrowing against high-priced real estate could increase the financial fragility of the region. In a related and quite interesting paper, Owen Lamont and Jeremy Stein show that, in cities in which households are more leveraged, volatility in house prices is greater. ${ }^{6}$ 
Figure 1. Ratios of Mortgage Debt to Disposable Personal Income and to Real Estate Market Value, 1952-2000 ${ }^{\mathrm{a}}$

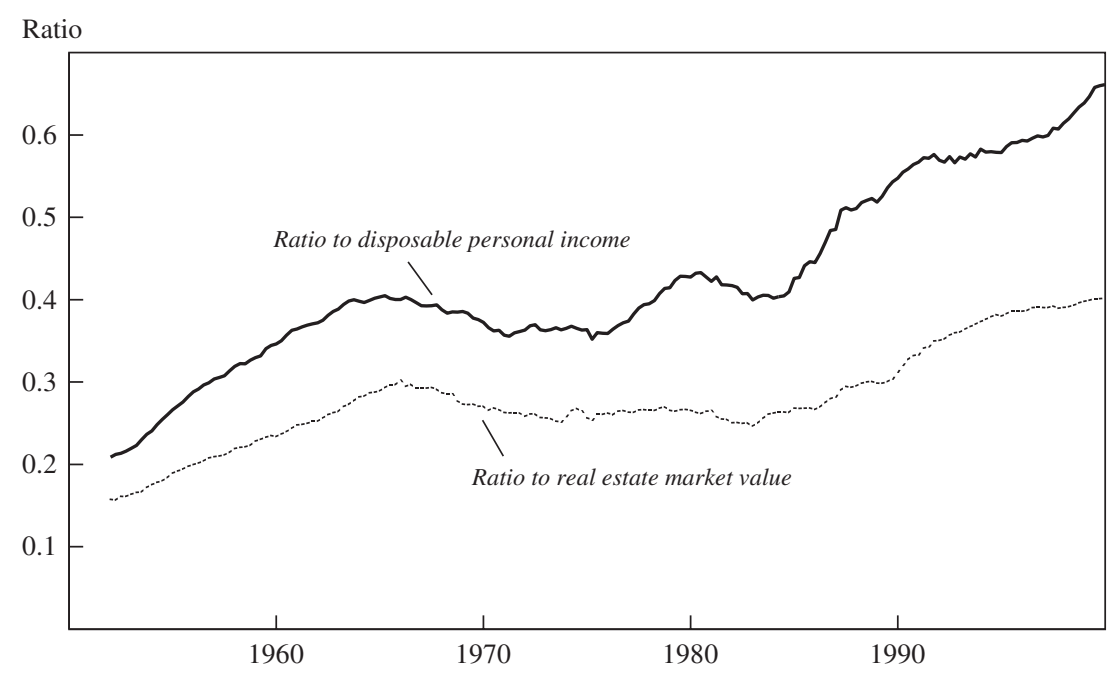

Source: Federal Reserve, Flow of Funds Accounts. a. Through first quarter.

Finally, cyclical movements in real estate prices provide some potentially important clues to the sources of economic development and cycles. In thinking about real estate booms, one must ask why such a boom is ever regional. Case discusses regional booms as if they are a natural phenomenon, but why does economic activity seem so tied to a specific location? The price differentials between San Francisco and most other cities in the country imply that the costs to a technology firm of moving out of the San Francisco area are enormous. Why does out-migration of jobs not reduce the price pressure? Instead one observes in-migration of workers. Spatial agglomeration is surely at the heart of this issue, and here real estate cycles may have a lot to teach us.

Let me conclude by pointing out that, at least along one dimension, the real estate market appears more fragile than it was at the end of the previous expansion. Note that stability, or absence of propagation of shocks, decreases with leverage. Although real estate prices have not risen as much as they did in the last expansion, mortgage debt is higher relative to both disposable personal income and the market value of residential real estate. Figure 1 shows that the ratios of mortgage debt to each of these series are at historical highs. Mortgage debt rose significantly from the 1950s until 
the mid-1960s and remained roughly constant until the mid-1980s. I think that the Tax Reform Act of 1986, which, as noted above, preserved the tax deductibility of mortgage interest and only mortgage interest, is an important causal factor here. To go further, these large levels of mortgage debt may mean that the housing market-and the banking sector-are more vulnerable to a negative shock to the economy than they were in 1990.

In summary, I think that movements in housing prices have a significant effect on consumption, although one must keep in mind that there is surely also an effect of consumption demand on house prices. I postulate that policy changes that altered the effective price of housing, particularly the Tax Reform Act of 1986, may well explain much of that movement. The real estate market has much to tell us about the sources of fluctuations and growth, and I commend the author for providing this tour of the details of recent market developments. Finally, I do not see much evidence that the real estate market is more stable today than it was at the end of the 1980s.

General discussion: Robert Gordon reasoned that examining a longer period, such as the last fifty years, would provide far more variation in real estate markets from which to draw inferences. Although the 1986 tax reform, which the paper emphasized, was an important factor influencing real estate markets, earlier events and other aspects of financial deregulation may have been equally important. The extraordinary inflation in housing for the country as a whole occurred in the 1970s, and it was followed by serious financial problems among lenders. Bank deregulation over the 1978-85 period had major consequences for the thrift industry, which for years had been the main source of housing finance. And more recently, shopping for second mortgages and home equity loans on the Internet has made those markets more competitive and accessible to homeowners. Henry Aaron observed that the high inflation of the 1970s interacted with the tax system to make homeownership especially desirable, since the nominal appreciation of home values is essentially tax free, whereas mortgage interest payments are tax deductible. This contributed to the rise in house prices and magnified the wealth gains from real estate, which in that decade were far larger than those from the stock market.

Several panelists discussed Alan Greenspan's estimate, cited by Case, of a 5 percent propensity to spend out of changes in housing wealth. Gregory Mankiw pointed out that the increase in wealth from housing appre- 
ciation and the higher cost of housing cancel each other, suggesting that this propensity should be near zero. Robert Hall observed that, more formally speaking, a homeowner's consumption possibilities rotate around his or her endowment point, leaving no wealth or income effect. Mankiw questioned the empirical importance of two exceptions to the rule that had been mentioned: older homeowners who do not plan to leave their home as a bequest and homeowners who have benefited from appreciation in their own neighborhood but plan to move elsewhere. He had no view on the importance of liquidity-constrained consumers who use their appreciated home as collateral for a home equity loan.

In this connection, Mark Gertler reported on a study from the Bank of England that found a close connection between movements in house prices and borrowing against real estate, suggesting that this avenue might well justify Greenspan's estimate. Shang-Jin Wei observed that, in economies like Hong Kong and Japan, borrowing against real estate values has been a major source of credit expansion and contraction for business if not for consumers. George Akerlof suggested that a positive propensity to spend out of housing wealth could be understood by applying $q$ theory to residential construction. With construction costs determining the replacement cost of housing and the cost of home improvements, higher market values for existing homes may induce home improvements or the construction of new homes. Matthew Shapiro noted that even if housing wealth is an unlikely source of shocks to the economy, housing may nonetheless be important in propagating shocks from other sources. Suppose the desired stock of housing falls because of a change in wealth, for example, from a sharp decline in the stock market. The downward adjustment in the housing stock relative to the current trend could lead to a prolonged recession in the construction industry.

Dale Jorgenson applauded the detailed data on real estate prices that Case had assembled and noted that they do not show the generalized U.S. asset price bubble that some commentators have warned of. He also emphasized that major real estate crises have not generally been part of the national business cycle but rather have reflected regional booms and busts. The oil price collapse in the mid-1980s was responsible for the Texas crisis, and defense cutbacks were key in the crashes at the end of the decade in California and Massachusetts. He noted that increased securitization that spreads mortgage exposure geographically and away from mortgage originators could lessen such problems of concentration in the future. 


\section{References}

Attanasio, Orazio P. 1998. "Cohort Analysis of Saving Behavior by U.S. Households." Journal of Human Resources 33(3): 575-609.

Browne, Lynn F., and Karl E. Case. 1992. "How the Commercial Real Estate Boom Undid the Banks." In Real Estate and the Credit Crunch, edited by Lynn F. Browne and Eric S. Rosengren. Federal Reserve Bank of Boston Conference Series 36. Boston: Federal Reserve Bank of Boston (September).

Carroll, Christopher D. 2000. "Why Do the Rich Save So Much?” In Does Atlas Shrug? The Economic Consequences of Taxing the Rich, edited by Joel B. Slemrod. Harvard University Press.

Case, Karl E. "The Market for Single-Family Homes in Boston, 1979-1985." New England Economic Review (May-June), pp. 38-48.

_ 1991. "The Real Estate Cycle and the Economy: Consequences of the Massachusetts Boom of 1984-1987." New England Economic Review (September-October), pp. 37-46.

Case, Karl, and Christopher J. Mayer. 1995. "The Housing Cycle in Eastern Massachusetts: Variation among Cities and Towns." New England Economic Review (March), pp. 24-35.

1996. "Housing Price Dynamics within a Metropolitan Area." Regional Science and Urban Economics 26(3-4): 387-407.

Case, Karl E., and Robert J. Shiller. 1987. "Index-Based Futures and Options Markets in Real Estate." Journal of Portfolio Management 19(2): 83-92.

. 1988. "The Behavior of Home Buyers in Boom and Post-Boom Markets." New England Economic Review (November-December), pp. 29-47.

. 1989. "The Efficiency of the Market for Single Family Homes." American Economic Review 79(1): 125-37.

1990. "Forecasting Prices and Excess Returns in the Housing Market." Journal of the American Real Estate and Urban Economics Association 18(3): 253-73.

1994. "A Decade of Boom and Bust in the Prices of Single-Family Homes: Boston and Los Angeles, 1983 to 1993." New England Economic Review (March-April), pp. 40-52.

1996. "Mortgage Default Risk and Real Estate Prices: The Use of IndexBased Futures and Options in Real Estate." Journal of Housing Research 7(2): 243-58.

. Forthcoming. "The Stock Market, the Housing Market, and Consumer Spending." Paper prepared for the annual meeting of the American Economic Association.

Clayton, Jim. 1997. "Are House Price Cycles Driven by Irrational Expectations?" Journal of Real Estate Finance and Economics, 14(3): 341-63. 
Deaton, Angus, and Christina Paxson. Forthcoming. "Growth, Demographic Structure and National Saving in Taiwan." Population and Development Review.

Dynan, Karen E., Jonathan Skinner, and Stephen P. Zeldes. 2000. "Do the Rich Save More?" Working Paper 7906. Cambridge, Mass.: National Bureau of Economic Research (September).

Federal Deposit Insurance Corporation. 1998. Managing the Crisis: The FDIC and RTC Experience 1980-1994. Washington.

Follain, James R., and Stephen Malpezzi. 1981. "Are Occupants Accurate Appraisers?" Review of Public Data Use 9(1): 47-55.

Gentry, William M., and R. Glen Hubbard. 1998. "Entrepreneurship and Household Saving." Unpublished manuscript. Columbia University (July).

Goodman, John L., and John B. Ittner. 1992. "The Accuracy of Home Owners' Estimates of House Value." Journal of Housing Economics 2(4): 339-57.

Green, Richard K. 2000. "Stock Prices and House Prices in California: New Evidence of a Wealth Effect? A Note." Unpublished paper. University of Wisconsin, Madison.

Hurst, Erik. 1998. "Household Consumption and Household Type: What Can We Learn from Mortgage Refinancing?" Unpublished manuscript. University of Michigan (November).

Kain, John F., and John Michael Quigley. 1972. "Note on Owners' Estimate of Housing Value." Journal of the American Statistical Association 67(340): 803-06.

Lamont, Owen, and Jeremy C. Stein. 1999. "Leverage and House-Price Dynamics in U.S. Cities.” RAND Journal of Economics 30(3): 498-514.

Mankiw, N. Gregory, and David N. Weil. 1989. "The Baby Boom, the Baby Bust, and the Housing Market." Regional Science and Urban Economics 19(2): 235-58.

Miles, Mike, and Nancy Tolleson. 1997. "A Revised Look at How Real Estate Compares with Other Major Components of Domestic Investment Universe." Real Estate Finance (Spring).

Moscovitch, Edward. 1990. "The Downturn in the New England Economy. What Lies behind It?" New England Economic Review (July-August), pp. 53-65.

Office of Federal Housing Enterprise Oversight. 1999. 1999 Report to Congress. Washington.

Parker, Jonathan A. 1999. "Spendthrift in America? On Two Decades of Decline in the U.S. Saving Rate.” In NBER Macroeconomics Annual 1999, edited by Ben S. Bernanke and Julio Rotemberg. MIT Press.

Paxson, Christina. 1996. "Saving and Growth: Evidence from Micro Data." European Economic Review 40(2): 255-88.

Poterba, James M. 2000. "Stock Market Wealth and Consumption.” Journal of Economic Perspectives 14(2): 99-118. 
Quadrini, Vincenzo. 2000. "Entrepreneurship, Saving, and Social Mobility." Review of Economic Dynamics 3(1): 1-40.

Skinner, Jonathan S. 1996. "Is Housing Wealth a Sideshow?" In Advances in the Economics of Aging, edited by David A. Wise. University of Chicago Press.

Tracy, Joseph, Henry Schneider, and Sewin Chan. 1999. "Are Stocks Overtaking Real Estate in Household Portfolios?" Federal Reserve Bank of New York Current Issues in Economics and Finance 5(5): 1-6. 